\title{
傷害性神経因性疼痛誘発を担う リゾホスファチジン酸
}

要約：神経傷害に伴い誘導される慢性疼痛は難治性神 経因性疼痛と呼ばれ，抗炎症薬や強力な鎮痛作用を有 するモルヒネによって除痛されにくい，従って，急性 の痛みとは仕組みが全く異なり, 未梢神経傷害に伴う 一次知覚神経と脊髄での可塑的機能変調がその基盤と なると考えられる，著者らは近年，神経傷害後，長期 に認められる痛覚過敏・アロディニア現象を誘導する 初発原因分子として脂質メディエーターであるリゾホ スファチジン酸（LPA）を同定した。このLPAは後 根神経節や脊髄後角における疼痛伝達分子の発現増加 や一次知覚神経の脱髄現象を誘導し，これらがそれぞ れ痛覚過敏やアロディニア現象の分子基盤となること が明らかになった。

\section{1.はじめに}

1988 年 Bennet らがラット坐骨神経の部分傷害によ る神経因性疼痛動物モデル作成に成功して以来, いく つかの関連する動物モデルが報告され，利用されてき た(1)。これらに共通することは，いずれの場合も知 覚神経入力の全結紮でなく, 部分的な傷害に基づくも のであった。このことは，傷害を受けた神経そのもの の病変が症状を反映するのではなく, 傷害の結果生ず る新たな液性因子が, 知覚入力の可塑的再編成を誘発 することを示唆するものである，我々は，2004 年こ の神経因性疼痛を誘発する因子がリゾホスファチジン 酸（LPA）であることを突き止めることに成功した (2). 本項では神経因性疼痛の分子機構について, 最近の 我々の研究成果を紹介する.

\section{2. 神経因性疼痛モデルにおける可塑的変調}

ヒトにおいて，そして動物モデルにおいて観察され
る代表的神経因性疼痛症状は疼痛過敏とアロディニア である．アロディニアは触刺激によっても灼熱痛を感 じるような異常痛であり, 触覚を伝える有髄太径 $\mathrm{A} \beta$ 神経線維と痛覚を伝える無髄細径 C 神経あるいは有髄 中径 $\mathrm{A} \delta$ 神経線維の間の機能的交差によるものである と理解される。この機能的交差は，有髄線維が脱髄時 に誘発されるスプラウティング (異常発芽) にもとづ くエファプス（線維間の物理的接触）や脊髄後角二次 神経における（触覚から痛覚への）誤入力として概念 づけられる（図 1 )。一方疼痛過敏は，知覚神経や春 䯣後角における疼痛伝達に関与する機能分子の遺伝子 発現変化として説明される. 神経因性疼痛のもう一つ の重要な特徵は慢性化にある.すなわち維持機構とさ らに発展した記憶メカニズムがその役割を果たすもの と考えられるが，その穾態は明らかにされていない。

しかし最近，春髄においてミクログリアの活性化が認 められ，様々な神経栄養因子やサイトカイン産生を介 した神経回路, 伝達の可塑的強化が期待されている. ヒトの場合，様々な理由から病態が長期にわたると， 春髄から上位脳における可塑的変調へとシフトし, 海 馬などにおける痛み記憶と下位脳幹部から脊髄後角へ の下降性疼痛入力抑制系への影響など関わり, 慢性痛 が固定されることが予想される。

\section{3. 痛み伝達分子の表現型変換の分子基盤}

このような可塑的変化を担う分子基盤として明らか になっているのは主に後根神経節（DRG）における 遺伝子発現変化である. 様々な遺伝子発現変化が報告 されているが，神経因性疼痛病態と強く関連づけられ ているものとして, 侵害受容や伝導, 脊髄疼痛伝達に 関与する受容体，イオンチャネルや神経ペプチドなど

キーワード : 神経因性疼痛, リゾホスファチジン酸, 脱髄, ボツリヌス毒素 $\mathrm{C} 3$, アロディニア

長崎大学大学院 医歯薬学総合研究科 分子薬理学分野 ( $852-8521$ 長崎市文教町 1-14) e-mail: ueda@net.nagasaki-u.ac.jp＼cjkstart原稿受領日：2005 年 11月 30 日，会誌編集員会依頼原稿 Title: Lysophosphatidic acid as initiator of neuropathic pain Author: Hiroshi Ueda 
が報告されている(1).なかでも，これまでマウス坐 骨神経部分結紮モデルを用いて著者らが明らかにして きた疼痛伝達の表現型に可塑的な影響を及ぼす遺伝子 発現変化として, 以下のようなものを見出している.

・正常時 $\mathrm{C}$ 線維細胞に限局発現するカプサイシン受容 体（TRPV1）の有髄 A 線維細胞における新たな発現 ・正常時 C 線維細胞に限局発現するブラジキニン $\mathrm{B} 2$ 受容体発現の消失と, 有髄 $\mathrm{A}$ 線維細胞におけるブラ ジキニン B1 受容体の新たな発現

・代表的な C 線維伝達物質であるサブスタンス P の春 髄後角における発現低下

・C 線維細胞に扔けるモルヒネ受容体 (MOP) の発 現と末梢性モルヒネ鎮痛の消失

・正常時 $\mathrm{C}$ 線維細胞に限局発現するカルシウムチャネ ルサブユニット $\left(\mathrm{Ca}_{\mathrm{v}} \alpha 2-\delta 1\right)$ の有髄 $\mathrm{A}$ 線維細胞に おける新たな発現

こうした一連の事実は神経因性疼痛モデルにおいては, 痛み情報伝達が, 閾值が高く伝導速度の遅い無髄 C 線 維から閾值が低く伝導速度の速い有䯣 $\mathrm{A}$ 線維に大きく シフトしていることを示唆しており, 疼痛過敏の一つ の分子基盤をなすと考えられる。

\section{4. 神経因性疼痛誘発における初発分子として のLPA}

我々が神経因性疼痛の原因分子としてLPA を発見 し得た理由の一部には, 偶然の幸運があったことは否 めない. 最初にその発見に至る発想の経緯について少 し触れてみたい。

\section{1 ) $\mathbf{L P A}_{1}$ 受容体とその細胞機能}

$\mathrm{LPA}_{1}$ 受容体はもともと VZG1（EDG2）として脳神 経新生時に脳室周囲 subventricular zone に超高発現す る GPCR として初めて発見されたものであるが $(3,4)$, 著者はこの受容体に興味を抱き，その情報伝達機構の 解析を通じて $\mathrm{LPA}_{1}$ 受容体研究に関わってきた。バキ ユロウイルスに受容体遺伝子と $\mathrm{G}$ タンパク質 3 量体全 てのサブユニットの 4 分子を, 種類を変えて同時強制 発現させる研究を行ったところ, $\mathrm{G} \alpha_{\mathrm{i}} \beta \gamma, \mathrm{G} \alpha_{0} \beta \gamma$, $\mathrm{G} \alpha_{11} \beta \gamma$ のいずれとも連関することを初めて再構成 実験として証明した $(3,5)$ 。興味あることは $\mathrm{G}_{\mathrm{i}}$ と連関 した場合にのみ，この受容体に固有活性が認められた ことである. $\mathrm{LPA}_{1}$ 受容体が $\mathrm{G}_{\mathrm{i}}$ を介して細胞増殖を増 加することを考えると, 神経新生時に超高発現される $\mathrm{LPA}_{1}$ 受容体自身がリガンド刺激無しでも神経幹細胞 増殖に寄与する可能性があるとして注目される。
$\mathrm{LPA}_{1}$ 受容体がもっとも注目される情報伝達機構は, $\mathrm{G}_{12 / 13}$ とRho-Rho キナーゼ (ROCK) を介した細胞 形態変化との関連である.とくにボッリ又ス毒素 C3 （BoTXC3）がRhoA を特異的に阻害することから， 様々な細胞生理機能解明に用いられてきた. 多くの細 胞ではLPA は高度なアクチン重合によりストレスフ アイバーを形成するが, 神経細胞ではその重合は細胞 体領域で起こるため, むしろ末端にある神経突起は細 胞体方向に引き込まれるようにして突起の退縮を生ず ると考えられている(6). いずれにしても，このメカ ニズムにより細胞の形態は大きく変容することは共通 する事実である。一方, $\mathrm{LPA}_{1}$ 受容体には 2 つのスプ ライス変異が存在するが, このうち Long form の変異 体発現の発生, 生後発達を観察した研究では, $\mathrm{LPA}_{1}$ 受容体は生後脳において大半がミエリン領域に見出さ れるが，ミエリン形成の一時期に特に高く発現するこ とが報告されている(7). 発現そのものは中枢のオリ ゴデンドロサイトのみならず末梢の Schwann 細胞に も見出され何らかの重要な役割が予想されてきた。受 容体遺伝子の点変異に関する報告があり, ある少数の 家系の脱髄性ニューロパチーとの関連を解析したが, 特に明確な相関性は見出されず, 他の病態家系の解析 の必要性が指摘されている(7).

\section{2) LPAによる神経因性疼痛様作用発現}

我々は 10 年近く以前から，マウスの後肢足蹠皮下 （i.pl.）に発痛物質を微量投与することで生じる侵害 性屈曲応答を評価する研究を行ってきた (1)，超高感 度分析や in vivo 情報伝達機構解析や疼痛誘発責任神 経細胞の同定が可能であることから，不特定の生理活 性物質の薬理作用を侵害性応答あるいは鎮痛作用とし て検出, 解析することが可能であった。 そこで, LPA (i.pl.) の適用を試みたところ，有意な侵害応答が観 察された。詳細は省くが，この効果は $\mathrm{LPA}_{1}$ 受容体を 介し, サブスタンス P を伝達物質とする C 線維を活性 化することによることが明らかになった $(8,9)$.この ことに触発されて, LPAを春髄くも膜下腔内に単回 投与したとき，驚くべきことに1-2 日後に始まり，1 週間以上も持続する疼痛過敏反応が観察された (2). ここで観察した疼痛検定法はいわゆる Tail Flick 法や Hargreaves 法と呼ばれる後肢足底部に熱線を適用し, その回避行動を測定する熱刺激試験と von Frey 法変 法とも呼ばれる paw pressure 法, すなわち後肢足底 部に可変圧力を適用しその回避に必要な圧力を測定す る方法である。

\section{3) BoTXC3により遮断される神経因性疼痛}

多発性硬化症, ギラン・バレー症候群あるいはシャ 
ルコ・マリー・ッース病（CMT）など多くの脱髄性 疾患は神経因性疼痛を伴うことが知られている。また ミエリン形成と密接な関連が示唆されている $\mathrm{LPA}_{1}$ 受 容体 (7)，また脱髄などの形態的変化に Rho ファミリ ー Gタンパク質が関与している事実(10)を踏まえ, 神経傷害-LPA 産生-LPA1 受容体活性化-Rho-ROCK システム活性化 - 脱䯣という図式を想定した。最初に 試みたのは RhoA 阻害薬である BoTXC3 処置であった。 坐骨神経部分結紮による熱的過敏応答や機械的アロデ イニア作用は，BoTXC3 のくも膜下腔前投与により完 全に遮断された(11)。

\section{$4) \mathbf{L P A}_{1}$ 受容体遺伝子欠損動物 ( $\mathrm{LPA}_{1} \mathrm{KO}$ マウス) における神経因性疼痛消失}

これまでに神経因性疼痛を様々な角度から解析評価 し, さらにLPA (i.t.) 単回投与がその殆どの病態, 分子機構を再現することを見出してきた (2)。これら 全てが $\mathrm{LPA}_{1} \mathrm{KO}$ マウスにおいて消失した。対照とし て $\mathrm{LPA}_{2} \mathrm{KO}$ マウスを用いたが，全く影響が観察され なかった。これは, 知覚線維や後根神経節細胞に $\mathrm{LPA}_{2}$ 受容体が発現しないことと一致する。またLPA 受容体と同じファミリーに属するスフィンゴシン 1 リ ン酸（S1P）受容体リガンドである S1Pに神経因性疼 痛誘発作用は認められなかったことから, この受容体 応答の特異性が認められた。神経因性疼痛の特徵であ る疼痛過敏応答に直結する効果としてカルシウムチャ ネル $\mathrm{Ca}_{\mathrm{v}} \alpha 2-\delta 1$ の A 線維神経における発現上昇や脊 髄後角レベルに打ける PKC 発現上昇がそれに当たる. アロディニアのメカニズムは十分に明らかにされてい ないが，信頼できる仮説としてエファプスによる線維 間の混線や後角レベルでの触覚線維や機械的刺激受容 C 線維の熱的刺激受容線維への䛊入力があげられてい る. エファプスや誤入力には脱髄による絶縁除去やス プラウティングが関わるとされるが, 坐骨神経部分結 禁や LPA（i.t.）単回投与が脊䯣後根において著明な 脱髄を誘発し，その効果は $\mathrm{LPA}_{1} \mathrm{KO}$ マウスにおいて 完全に消失した。神経因性疼痛時の誤入力において, 後角における新規投射先に新たな投射空間が必要とな るが，C 線維の神経伝達物質であるサブスタンス P の 後角における発現の著明な消失が観察されることを見 出している. LPA (i.t.) 単回投与によっても再現でき るが,これらの現象も $\mathrm{LPA}_{1} \mathrm{KO}$ マウスにおいて完全 に消失した。

\section{5 ) 神経因性疼痛発現の初発原因分子としてのLPA}

$\mathrm{LPA}_{1} \mathrm{KO}$ マウスに扮いて, 多くの神経因性疼痛病態, あるいはそのメカニズムが消失した事実は, 内在性の LPA がその受容体に働くことがそのメカニズムをな
すことを証明している．コンディショナル KO マウス が利用できるまで，十分な回答はできないが，LPA が神経因性疼痛の原因分子であるという仮説は, BoTXC3 や $\mathrm{LPA}_{1}$ 受容体遺伝子アンチセンスオリゴデ オキシヌクレオチド（AS-ODN）の適用により証明で きた. BoTXC3 効果は坐骨神経傷害の前処置 1 時間か ら後処置 1 時間までで完全に, その後 6 時間後では効 果は認められなかった。もう少し長いスパンでの効果 はAS-ODN（i.t.）処置で観察された. AS-ODN 処置 は傷害の 5 日前から隔日に投与し, 傷害後 7 日目には $\mathrm{LPA}_{1}$ 受容体のウェスタンブロットにおけるタンパク 質発現は著明に減少し, アロディニアも消失した。 そ の後 AS-ODN 処置を停止し, その 1 週間後には $\mathrm{LPA}_{1}$ 受容体レベルが回復したが，アロディニア消失は回復 しなかった。逆に，AS-ODN 投与を 1 週間後から開 始し 2 週間後には $\mathrm{LPA}_{1}$ 受容体レベルは低下したが, すでにアロディニアは残存したままであった。

\section{6 ）培養実験におけるLPA誘発性脱髄の証明}

LPA は生体内に存在する数多くの細胞にその受容 体を有し, 幅広い生理的役割を果たしているため, LPAの神経線維に及ぼす効果が二次的なものでない ことを証明する必要がある。この目的のために知覚神 経線維を摘出し, ex vivo 培養系において, 直接 LPA による脱髄応答を評価する方法を確立した。 LPAを $0.1 \mu \mathrm{M}$ 添加しおよそ 24 時間から 36 時間後において, 著明な脱髄とスプラウティングが観察された。分子機 構については大きな課題であるが，個体レベルでも観 察されるようにミエリンタンパク質の有意な発現低下 がこの培養実験においても観察された.さらに強力な 証拠は DRG 神経細胞と Schwann 細胞との共培養に おいても LPAによる形態的，ミエリンタンパク質発 現低下が観察され, BoTXC3により遮断された。

興味あることは，坐骨神経部分結禁によるモデルで $\mathrm{LPA}_{1} \mathrm{KO}$ マウスにおいて消失する脱髄は脊髄後根に限 られるという事実である。このことを ex vivo 実験で 再現しょうと試みたが, 程度の差こそあれ, 坐骨神経 線維, 脊髄神経線維, 後根線維のいずれにおいても LPA 誘発性脱髄が観察された。すなわち, $\mathrm{LPA}_{1}$ 受容 体を介する脱髄応答の差は線維の特性にあるというょ り, LPA が脊髄後根近傍で産生されることを示唆し ている.

\section{7 ) LPA産生機構}

脊髄後根は末梢の神経線維とは異なり，比較的脊䯣 液からの物質を受けやすいと考えられることから， LPA 産生は脊髄にあるという可能性がある。 LPA は 細胞内でも産生されるが, 最近の理解では細胞外の 


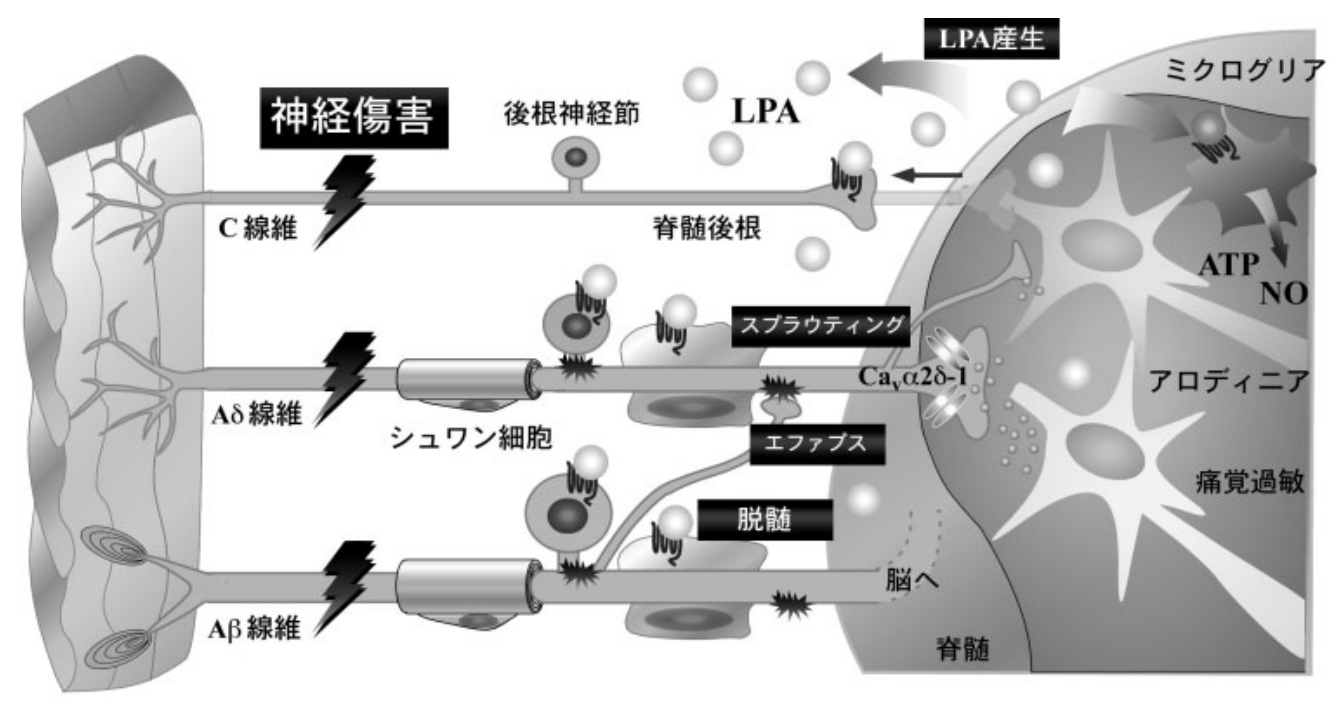

図 1 リゾホスファチジン酸による神経因性疼痛誘導・維持機構に関する仮説図

神経障害に伴い春賄において LPA が産生・遊離され，一次知覚神経の脊髄後根を取り巻くシュワン細胞に作用し脱髄を誘発する。脱髄した神 経は他の神経との電気的混線（エファプス）や異常突起伸展（スプラウティング）を誘導する. 一方, LPAは後根神経節細胞にも作用し $\mathrm{Ca}_{v} \alpha 2 \delta$ - 7 発現上昇を誘導する。 これらの現象により, アロディニアや痛覚過敏現象が形成される。ささらに，LPAは脊髄におけるミクログリ アなどにも作用し，ATPやNO を産生し，神経因性疼痛の維持にも関与する可能性が推測される。

LPA は活性化を受けて細胞表面に表れる合成酵素 , リ ゾホスホリパーゼ D（LPLD）の働きによるとされて いる(12)，基質としては血液中などあらゆる細胞外液 に豊富に存在するリゾホスファチジルコリン（LPC） が主たるものであるが, 律速段階は LPLD の活性化に ある。このテーマは多くの細胞科学分野で話題になっ ているが十分に明らかにされていない領域である。た だ，LPLD は細胞膜というょり小胞状の細胞内構造物 に存在することが報告され，特定の刺激に応じて活性 化分泌される可能性が示唆されている(12). 従って, 神経傷害により一時的に脊髄後角で伝達物質放出が起 こり, LPLD が過剩活性化を受ける可能性は高い。脊 髄くも膜下腔への LPLD の AS-ODN 投与により神経 因性疼痛が減弱を受けるという予備試験結果を踏まえ ると，この可能性は十分期待される.

\section{8 ) 神経因性疼痛の維持機構としてのLPAによる春髄} ミクログリア活性化

もし, 脊髄で LPA が産生されるなら, 春䯣内でも LPAによる細胞応答が発生しても不思議ではない。 実際 LPA はミクログリアを活性化できるし，その結 果 ATP 放出を引き起こし, さらなる ATP 効果による 慢性化に導きうる。活性化を受けたミクログリアは 様々な神経栄養因子やサイトカイン, NO 産生や COX-2 発現を介して, 神経回路の可塑性の誘導や維
持に機能する可能性も期待される.

\section{5. おわりに}

LPA が神経因性疼痛の発症機序を担っていること を証明し，場合によっては脊髄においてミクログロア 活性化を通じて，さらに神経回路の可塑性維持にも機 能しているという可能性を示唆することができた。し かし残された課題には, この研究の臨床応用可能性と このメカニズムの普遍性がある．前者では術後痛や進 行性の神経因性疼痛に適用可能であるということ, 後 者では，予備的ではあるがいくつかの異なるモデルで も有効であるという知見を有している，LPAに始ま る様々な生理機構が病態の維持に働きうるので, こう した仕組みをさらに解明することで新たな治療戦略が 立てられるものと考えられる。

謝辞：本研究で用いた $\mathrm{LPA}_{1}$ および $\mathrm{LPA}_{2} \mathrm{KO}$ マウスは Scripps 研究所 J Chun 博士から共同研究として譲渡された ものである.また LPLDに関する知識, 共同研究について は東京大学青木淳賢先生のご協力に大変感謝しています. 本研究および本執筆においては当研究室の多くの学生, ス タッフの協力を得て完成できたものであり，ここに感謝の 意を表します。 


\section{文}

献

1) Ueda H. Pharmacol Ther. 2005;109:57-77.

2) Inoue $M$, et al. Nature Med. 2004;10:712-718.

3) Yoshida A , et al. Jpn J Pharmacol. 2001;87:104-109.

4) Chun J, et al. Pharmacol Rev. 2002;54:265-269.

5) Yoshida A, et al. Biochem Biophys Res Comm. 1999;259:78-
84.

6) Zhang $X-F$, et al. Neuron. 2003;40:931-944.

7) Allard J, et al. Glia. 1999;26:176-185.

8) Renback K, et al. Neurosci Lett. 1999;270:59-61.

9) Renback K, et al. Mol Brain Res. 2000;75:350-354

10) Brancolini C, et al. Mol Biol Cell. 1999;10:2441-2459

11) Ye X, et al. Jpn J Pharmacol. 2000;83:161-163.

12) Moolenaar WH, et al. Bioessays. 2004;26:870-881.

\section{著者プロフィール}

\section{植田弘師（うえだ ひろし）}

長崎大学大学院医歯薬学総合研究科 分子薬理学分野, 教授, 薬学博士.

$\diamond 1976$ 年 京都大学薬学部卒業, ' 81 年同大学院博士課程修了, 横浜市立大学医学部薬理学助手, 京都大学薬学部助手, 横浜市立大学医学部助教授を経て現在に至る。研究テーマ: 神経因性疼痛の分子機序解明, オピオイド依存時の 脳神経回路可塑的再編成の可視化, 脳卒中を保護する分子の発見と解析, 統合失調症抒よびうつ病とシナプス形態 変化.

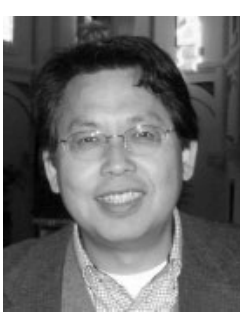

